GRADUATE SCHOOL

OF INDUSTRIAL ADMINISTRATION

WILLIAM LARIMER MELLON, FOUNDER

REPRINT NO. 907

\title{
Is the Federal Reserve's \\ Monetary Control Policy \\ Misdirected?
}

b)

Robert H. Rasche, Allan H. Molizer,

Peter D. Sternlight, and Stephen H. Axilrod

1082

S1 Carnegıe-Mellon Universıty

PITTSBURGH, PENNSYLVANIA 15213 


\section{Graduate School of Industrial Administration}

Willam Larimer Molion, Founder

\section{Carnegie-Mellon University}

Pittaburgh, Pennojtrania 15218

\section{SOME CURAENT REPRINTS}

878. On the Monetary Analysis of Exchange Rates. A Comment. Robert J. Hodrick.

879. The Elusive Medlan Voter. Thomas Romer and Howard Rosenthal.

881. Institutionalization of Planned Organizational Change. Paul S. Goodman, Max Bazerman and Edward Conlon.

883. Bureaucrats vs. Voters: On the Political Economy of Resource Allocation by Direct Democracy. Thomas Romer and Howard Rosenthal.

884. Rational Expectations and the Role of Monetary Policy. A Generalization. Alex Cukieg man.

885. Optimal Incentive Contracts with Imperfect Information. Milton Harris and Artur Raviv.

886. On the Use of Facet Analysis in Organizational Behavior Research: Some Conceptual Conaiderations and an Example. Zur Shapira and Ell Zevulun.

887. Writer-Based Prose: A Cognitive Basis for Problems in Writing. Linda Flower.

888. lasues and Models in Empirical Research on Aggregate Consumer Expenditure. Walter Dolde.

889. Rational Decislon Making in Business Organizations. Herbert A. Simon.

890. Optimal Contracts and Competitive Markets with Costly State Verification. Robert M. Towmend.

891. Towards a Better Microeconomic Theory. Richard M. Cyert and Garrel Pottinger.

892. The Effects of Rate-of-Return Regulation on the Intensity of Use and Durability of Capital. Dennis Epple and Allan Zelenitz.

893. Comparison of Experiments and Information Measures. Prem K. Goel and Morris H. Decroot.

894. Capital Allocation Within a Firm. R. M. Cyert, M. H. DeGroot, and C. A. Holt.

805. The Information Content of Discounts and Premiums on Closed-End Fund Shares. Rex Thompson.

896. Developing a Financial Planning Model for an Analytical Review: A Feasibility Study. Robert 8. Kaplan.

897. Evaluating the Quality of Information Systems. Charles H. Kriebel.

898. Strengthening Cuts for Mixed Integer Programs. Egon Balas and Robert G. Jeroslow.

899. Dynamic Optimal Taxation, Rational Expectations and Optimal Control. Finn E. Kydland and Edward C. Prescott.

900. The Effects of Uncertainty on Investment Under Risk Neutrality with Endogenous Information. Alex Cukierman.

901. Cutting Planes from Conditional Bounds: A New Approach to Set Covering. Egon Balas.

902. Set Covering Algorithms Using Cutting Planes, Heuristics, and Subgradient Optimization: A Computational Study. Egon Balas and Andrew Ho.

903. Stein's Paradox and Audit Sampling. Yuji ljiri and Robert A. Leitch.

904. Political Resource Allocation, Controlled Agendas, and the Status Quo. Thomas Romer and Howard Rosenthal.

905. A New and Efficient Algorithm for a Class of Portfolio Selection Problems. Jong-Shi Pang.

807. Recursive Competitive Equilibrium: The Case of Homogeneous Households. Edward C. Prescott and Rajnish Mehra.

909. Discussion. Scott F. Richard.

910. Comments on Externalities and Financial Reporting. Stanley Baiman.

911. The Cognition of Discovery: Defining a Rhetorical Problem. Linda Flower and John R. Hayes.

912. Four Essays on Procedural Rationality in Economics. Herbert A. Simon.

913. Pivot and Complement-A Heuristic for 0-1 Programming. Egon Balas and Clarence $\mathrm{H}$. Martin.

914. Organization Capital. Edward C. Prescott and Michael Visscher.

915. Recovery Rate and Cash Flow Accounting. Yuji tjiri.

916. Turnpike Horizons for Production Planning. Gerald L. Thompson and Suresh P. Sethi. (continued on inside back cover) 


\section{MONEY, CREDIT, AND \\ BANKING DEBATE}

$$
1
$$

\section{Is the Federal Reserve's Monetary Control Policy Misdirected?}

On October 6, 1979, the chairman of the Board of Governors of the Federal Reserve System announced a new operating procedure by which Federal Reserve open market operations were to be conducted to control unborrowed bank reserves directly rather than to control the Federal funds rate as previously. Subsequently there was increased variability in both interest rates and monetary growth. Why this happened and what if anything can be done to improve monetary control were the subjects of the Journal of Money, Credit, and Banking Debate held on April 30 , 1981, at the Ohio State University in Columbus.

Resolved:

That the Federal Reserve's current operating procedures for controlling money should be replaced

For the Affirmative:

ROBERT H. RASCHE, professor and chairman of the Department of Economics at Michigan State University and member of the Shadow Open Market Committee

Allan H. Meltzer, John M. Olin Professor of Political Economy and Public Policy at Carnegie-Mellon University and co-chairman of the Shadow Open Market Committee

For the Negative:

Peter D. Sternlight, manager of the Federal Reserve Open Market Account at the Federal Reserve Bank of New York

$0022-2879 / 82 / 0282-0119 \$ 00.50 / 0 \quad$ C) 1982 Ohio State University Press

Journal. of Money, Credit, And Banking, vol. 14, no. 1 (February 1982) 
StePhen H. Axilnod, staff director for Monetary and Financial Policy, Board of Governors of the Federal Reserve System

Moderator:

Congressman Chalmers $P$. Wylie from Ohio

FOR THE AFFIRMATIVE

RoBerT H. Rasche: There are two fundamental principles that underlie our support of the resolution. We believe there is no dispute between us and the Federal Reserve System over either of these principles.

First, we believe that inflation, such as we have experienced in the past decade, is destructive of the U.S. economy and must be arrested. Chairman Volcker, in recent testimony before the House Banking, Housing, and Urban Affairs Committee, has said that "experience here and abroad indicates unambiguously that we have not been successful in living with inflation-that in an economy like ours, persistent inflation, stagnation, and reduced productivity are inexorably related, and that left alone, inflation will get worse, not better."'

Until very recently economists had little quantitative information on the magnitude of the costs of inflation. Recent research, in particular that by Fischer, indicates that at inflation rates of the magnitude of 10 percent, the minimum welfare loss to the U.S. economy is around 3 to 4 percent of 1980 nominal GNP. ${ }^{2}$

Second, we believe that inflation, defined as the sustained rate of change of prices over a two-year to three-year period, can only be controlled if the money growth rate is reduced below the rates that have been observed during the last decade. This principle has also been advocated by the Federal Reserve System, most recently in the "Monetary Report to Congress" in February, where it is stated that "the basic premise of the System's policy is the broadly accepted notion that inflation can persist over appreciable spans of time only if it is accommodated by monetary expansion." "3 Our advocacy of this proposition is, therefore, not a dispute with the

'Paul A. Volcker, Committee on Banking, Housing and Urban Affairs, U.S. Senate (January 7, 1981).

"Stanley Fischer, "Towards an Understanding of the Costs of Inflation: II," mimeographed (Carnegie-Rochester Conference on Public Policy, November 1980).

${ }^{3}$ Board of Governors of the Federal Reserve System, Monetary Report to Congress (February 25,

1981), pp. 1-2. Other examples of the Federal Reserve System's acceptance of this principle are:

a. Arthur F. Burns, Committee on Banking and Currency, U.S. House of Representatives (July 30 , 1974): "This rate of growth (of narrowly defined money) is still too high for stability of average prices over the longer term.'

b. G. William Miller, Committee on Banking, Housing and Urban Affairs, U.S. Senate (April 25, 1978): "the FOMC ... remains firmly committed to a gradual reduction in monetary growth over time to rates more nearly consistent with reasonable price stability."

c. Paul A. Volcker, Committee on the Budget, U.S. House of Representatives (September 5, 1979): "the Federal Reserve intends to continue its efforts to restrain the growth of money and credit, a growth that in recent months has been excessive in terms of our own 1979 objectives."

d. Board of Governors, Monetary Report to Congress, pp. 1-2: "The basic promise of the system's policy is the broadly accepted notion that inflation can persist over appreciable spans of time only if it is accommodated by monetary expansion."

e. Ibid, p. 35: "The growth of money and credit will have to be slowed to a rate consistent with the long-range growth of nation's capacity to produce at reasonably stable prices." 
Federal Reserve over the end or the goal of monetary policy, but rather a disagreement with the system over the implementation of monetary policy to achieve this end.

We advocate that the Federal Reserve System adopt a money multiplier control procedure under which steady progress in reducing the money growth rate would be achieved and the policy objective of reduced inflation would be realized. This procedure would be implemented by:

1. Setting a target for the annual growth rate for the MIB money stock which, consistent with the historical relationship between that measure of money stock and nominal GNP, will bring the inflation rate down from its present levels. The target growth rate should be stated solely in terms of MIB to establish the accountability of the Federal Reserve System; however, our procedure will produce compatible changes in other monetary stock measures.

2. Adjusting money growth to aim at this target rate solely from the supply side. The issue of the relationship between interest rates and the demand for money does not enter into the control mechanism, and thus, the procedure overcomes the complaint frequently voiced by the Federal Reserve System that short-run shifts in the demand for money inhibit monetary control.

Therefore, our definition of a money multiplier procedure is the manipulation by the Federal Reserve System of the asset side of its own balance sheet in such a way as to bring about the desired rate of monetary growth. Such asset-side manipulation can be done in a number of ways, but our preferred implementation is the control of the monetary base, either gross or net of borrowings. Integral parts of this procedure are the following three institutional reforms:

1. Regulation $Q$ type ceilings should be eliminated. This reform is presently scheduled under the Depository Institutions Deregulation and Money Control Act of 1980. As part of the implementation of the money multiplier procedure, the Federal Reserve should publicly announce its desire that the phase-out of the ceilings proceed as rapidly as possible.

2. Contemporaneous reserve accounting should be restored. This reform is nothing more than a return to the institutional arrangements that prevailed prior to 1968 , and which proved workable in the absence of modern data processing and telecommunications technology.

3. The Federal Reserve discount rate should assume much more flexibility. Ideally, it should be floated; that is, it should be set in some fixed relationship to the federal funds rate, so that the major role of the discount window would be the lender

f. Ibid. p. 24: "Analysts of all schools agree that over the long-run, inflation cannot persist without monetary accommodation."

g. Paul A. Volcker, Committee on Appropriations, U.S. Senate (January 27, 1981): "If we truly face up to the job and successfully turn the corner in terms of inflationary expectations, then I believe the progress will come more readily."

h. Anthony M. Solomon, Eleventh Annual Banking Industry and Bank Stock Symposium of the Financial Analysts Federation (March 26, 1981), p. 2: "The broad strategy of monetary policy has been, and continues to be, structured around a gradual reduction over time in the growth of money and credit to rates consistent with acceptable price performance." 
of last resort function in truly unusual circumstances, and not the lender of best resort as it has been in recent years.

The last two of these reforms are completely within the administrative purview of the Federal Reserve System. ${ }^{4}$ Indeed, more flexibility in the administration of the discount rate was promised as part of the "October 1979 Package,' ' but is yet to be realized.

Under this procedure, the monetary base can be closely controlled through the Federal Reserve's open market operations in government securities. The behavior of the monetary base, averaged over weeks, months, quarters, years, or decades is dominated by the behavior of the following asset items: the Federal Reserve's portfolio of government securities, gold certificates and foreign exchange held by the Federal Reserve, and loans to financial institutions or borrowings. The latter would become insignificant under our proposal, and under a fluctuating exchange rate regime the Federal Reserve is under no compulsion to buy or sell gold or foreign exchange, or it can offset the impact of such changes on the monetary base by coincidental transactions in government securities.

Under such a money multiplier control procedure, control of money growth rates would not be exact, and we anticipate that "noise" would remain in the procedure from week to week or month to month. The source of such noise would be almost exclusively from forecasting errors for the money multiplier, the ratio of the MIB money stock to the monetary base. Thus an examination of the accuracy of forecasts of this variable can establish guidelines for the precision of the control procedure that we advocate.

There are numerous methods of forecasting a variable such as the money multiplier. We have implemented a particularly straightforward and inexpensive forecasting technique that takes advantage of the fact that the multiplier for any of the usual $M$ 's can be expressed as a function of a standard set of component ratios. ${ }^{5}$ Our procedures derive forecasts at any point in time exclusively from the information in the past history on the regularities in the behavior of the component ratios over time-so-called time series forecasting models. ${ }^{6}$ These techniques have been subjected to numerous tests and have proven extremely robust under a number of institutional settings. As such, the forecasting procedures require very little information to implement and provide a standard against which other forecasting procedures can be judged.

The evidence strongly suggests that under the procedure we propose, the money

${ }^{4}$ With respect to the administration of the discount rate, the intent of our procedure is the announced intent of the October 6, 1979, Federal Reserve Board actions. At that time the board announced that "regarding the administration of the discount window, the discount rate would be managed flexibly to discourage member bank borrowing," Federal Reserve Bulletin (October 1979): 831. Since that announcement, the average duration between discount rate changes (at the New York Federal Reserve Bank, excluding surcharges) has been 68.5 calendar days, and the rate has changed only seven times through April 12, 1981 .

${ }^{s}$ For detailed definitions of these variables, see James $M$. Johannes and Robert $H$. Rasche, "Can the Reserves Approach to Monetary Control Really Work," Journal of Money, Credit, and Banking 13 (August 1981): 298-313.

'James M. Johannes and Robert H. Rasche, "Predicting the Money Multiplier," Journal of Monetary Economics 5 (July 1979): 301-25. 
multiplier can be forecast with sufficient accuracy so that the growth rate of MlB can be maintained within a range of plus or minus 1 percent on an annual average basis. This is supported by the data in the table that I hope you can see distinctly (Table I).

TABLE 1

MULTIPI.IFR FORECASTS (ONE-MONTH-AHEAD FORECASTS)

\begin{tabular}{|c|c|c|c|c|c|c|c|}
\hline \multirow[b]{2}{*}{ Reserve Aggregate } & \multirow[b]{2}{*}{ Forecast Period } & \multirow{2}{*}{$\begin{array}{l}\text { (1) } \\
\text { Mean } \\
\text { Error }\end{array}$} & \multirow{2}{*}{$\begin{array}{r}\text { (2) } \\
\text { RMSE }\end{array}$} & \multirow{2}{*}{$\begin{array}{c}\text { (3) } \\
\text { First-Order } \\
\text { Auto-Correlation } \\
\text { in Errors }\end{array}$} & \multirow{2}{*}{$\begin{array}{c}\text { (4) } \\
\text { Relative } \\
\text { RMSE }\end{array}$} & \multirow{2}{*}{$\begin{array}{c}\text { (5) } \\
\text { Percent } \\
\text { Relative } \\
\text { RMSE } / \sqrt{3}\end{array}$} & \multirow[b]{2}{*}{$\begin{array}{c}\text { Relative } \\
\text { RMSE } / \sqrt{12}\end{array}$} \\
\hline & & & & & & & \\
\hline $\begin{array}{l}\text { St. Louis } \\
\text { adjusted } \\
\text { reserves }\end{array}$ & $\begin{array}{l}\text { Nov. } 78 \text {-Sept. } 79 \\
\text { Oct. } 79 \text {-Oct. } 80 \\
\text { Nov. } 78 \text {-Oct. } 80\end{array}$ & $\begin{array}{r}-0.0205 \\
0.0203 \\
0.0016\end{array}$ & $\begin{array}{l}0.0822 \\
0.1316 \\
0.1117\end{array}$ & $\begin{array}{l}-0.338 \\
-0.212 \\
-0.157\end{array}$ & $\begin{array}{l}0.92 \\
1.49 \\
1.26\end{array}$ & $\begin{array}{l}0.53 \\
0.86 \\
0.73\end{array}$ & $\begin{array}{l}0.27 \\
0.43 \\
0.36\end{array}$ \\
\hline $\begin{array}{l}\text { St. Louis } \\
\text { adjusted } \\
\text { nonborrowed } \\
\text { reserves }\end{array}$ & $\begin{array}{l}\text { Nov. } 78 \text {-Sept. } 79 \\
\text { Oct. } 79 \text {-Oct. } 80 \\
\text { Nov. } 78 \text {-Oct. } 80\end{array}$ & $\begin{array}{r}-0.0207 \\
0.0245 \\
0.0038\end{array}$ & $\begin{array}{l}0.0974 \\
0.1938 \\
0.1571\end{array}$ & $\begin{array}{l}0.040 \\
0.146 \\
0.166\end{array}$ & $\begin{array}{l}1.07 \\
2.12 \\
1.72\end{array}$ & $\begin{array}{l}0.62 \\
1.22 \\
0.99\end{array}$ & $\begin{array}{l}0.31 \\
0.61 \\
0.50\end{array}$ \\
\hline $\begin{array}{l}\text { St. Louis } \\
\text { monetary } \\
\text { base }\end{array}$ & $\begin{array}{l}\text { Nov. } 78 \text {-Sept. } 79 \\
\text { Oct. } 79 \text {-Oct. } 80 \\
\text { Nov. } 78 \text {-Oct. } 80\end{array}$ & $\begin{array}{r}-0.0025 \\
0.0014 \\
-0.0004\end{array}$ & $\begin{array}{l}0.0148 \\
0.0195 \\
0.0175\end{array}$ & $\begin{array}{r}-0.138 \\
0.302 \\
0.192\end{array}$ & $\begin{array}{l}0.58 \\
0.78 \\
0.70\end{array}$ & $\begin{array}{l}0.33 \\
0.45 \\
0.40\end{array}$ & $\begin{array}{l}0.17 \\
0.23 \\
0.20\end{array}$ \\
\hline $\begin{array}{l}\text { St. Louis } \\
\text { net monetary } \\
\text { base }\end{array}$ & $\begin{array}{l}\text { Nov. } 78 \text {-Sept. } 79 \\
\text { Oct. } 79 \text {-Oct. } 80 \\
\text { Nov. } 78 \text {-Oct. } 80\end{array}$ & $\begin{array}{r}-0.0025 \\
0.0016 \\
-0.0003\end{array}$ & $\begin{array}{l}0.0141 \\
0.0233 \\
0.0196\end{array}$ & $\begin{array}{l}0.135 \\
0.360 \\
0.332\end{array}$ & $\begin{array}{l}0.55 \\
0.93 \\
0.78\end{array}$ & $\begin{array}{l}0.32 \\
0.54 \\
0.45\end{array}$ & $\begin{array}{l}0.16 \\
0.27 \\
0.23\end{array}$ \\
\hline
\end{tabular}

Noil si Luis monetary base and net monetary base are adjusted for reserve requirements by the St. Louis Fed.

These data are generated from forecasting experiments beyond the sample period from which the models were constructed and a number of conclusions emerge from this table. First, errors on a month-to-month basis are appreciable. From the percent errors given in column 4 , you can see this, but there is no evidence that the errors persist systematically in one direction over time, as seen in column 3. As a result of this latter property, the average error over a calendar quarter or a year would be considerably smaller than those observed from month to month, with a consistent application of our proposal. This can be seen in columns 5 and 6 . Since the forecast errors do not persist, consistent implementation of the proposed procedure would eliminate the cumulative deviations from the growth rate targets that have been observed both before and after October 6, 1979. Finally, from the table you can see that the forecasting procedures have not deteriorated appreciably in the period since October 6, 1979, compared to the prior period.

Furthermore, these conclusions are not dependent upon these particular forecasting models. The Federal Reserve staff has recently presented evidence that their internal forecasting procedures have similar or even more desirable properties from the perspective of our procedure.

What benefits will accrue to the United States economy if our procedures were seriously pursued? First, if targets are set at consistently lower levels in successive years, as advocated under the president's program for economic recovery, and these targets are realized with the precision feasible under such a procedure, then the decade of the eighties will see the realization of reduced money growth that has been 
promised but not achieved by the Federal Reserve, and the U.S. economy will realize progress toward lower inflation rates.

Second, the reduction in inflation rates will come about with relatively low cost, since such a performance will alter present expectations of future inflation. We concur with Chairman Volcker's assessment that "patterns of inflationary behavior are by now so deeply ingrained in individual attitudes, that the process feeds on itself. That will change only when there is a visible, sustained commitment to policies that will in fact reduce the strong upward thrust of prices and permit market processes to penalize those speculating on inflation." 7

Third, the procyclical behavior of the money stock that the economy has experienced throughout the history of the Federal Reserve will be eliminated. Finally, the credibility of the Federal Reserve, which after a decade of failure to meet its stated objectives has been seriously eroded, will be restored. Again, in the words of Chairman Volcker: "Credibility in policy commitment will have to be earned by performance maintained through thick and thin."

We couldn't agree more.

FOR THE NEGATIVE

Peter D. Sternlight: Since October 1979, the Federal Reserve has sought to achieve its monetary growth objectives by aiming at associated reserve growth targets, while giving considerably less emphasis than previously to interest rates. The present technique represents a significant change from, and in my view improvement on, past procedures in providing better assurance of being able to reach desired growth targets.

It also has some costs in terms of greater short-run interest rate volatility and market uncertainty, but that should be a reasonable trade-off, to get better longerrun monetary control and restraint on inflation.

The change undertaken in October 1979 was essentially a change in means, not in ends. Both before and after that date, the Fed had sought to achieve growth rates for monetary aggregates chosen by the Federal Open Market Committee. The difference is that before October 1979 the Fed tried to bring about desired monetary growth by aiming at a particular federal funds rate, that is, the overnight interest charge on bank reserves. Estimates were made of the degree of reserve pressure, as indicated by the federal funds rate, that would tend to achieve desired monetary growth. Adjustments in the funds objective were then made as monetary growth was seen to be running above or below path.

In theory such an approach is quite feasible. There is a connection between

'Federal Reserve Bulletin (January 1981): 20. President Solomon of the New York Federal Reserve Bank also concurs in this assessment: "Psychologically speaking, public confidence that a slowing in money and credit growth will be achieved is also essential to the dampening of inflationary expectations, itself a critical requirement for achieving reasonably prompt progress on inflation," Eleventh Annual Symposium, p. 3.

Paul A. Volcker, Commmitee on Appropriations. 
pressure on reserve positions and monetary growth rates, and the omniscient uninhibited application of the technique should be able to produce the desired results. In practice the approach seemed to work reasonably well at times, but for significant periods, especially in the inflationary environment of recent years, adjustments to the funds rate objective tended to lag behind. Even though gradual changes could accumulate into sizable moves, the experience suggested a need for an approach that provided stronger assurance to the Federal Open Market Committee and the public of reaching desired results.

The change in October of 1979 was to focus operations on a reserve target instead of on the funds rate. The Open Market Committee still indicates a broad range for federal funds, but it has been a range of some 4 to 7 percentage points, in contrast to the one-half to one percentage point employed previously.

Moreover, and this is sometimes misunderstood, the broad funds range has not in practice been employed as an absolute limitation. It has been more in the nature of a check point, likely to be modified if operations proceed in such a way that it is tending to be breached in a significant fashion. As the markets are coming increasingly to understand, the funds rate may move outside the indicated range for a time. If that situation seems likely to persist, it is normally the occasion for further committee deliberation, in which short-term reserve targets can be reassessed in light of all the circumstances.

The relevant reserve targets are path levels of total and nonborrowed reserves (that is, other than those borrowed from the Fed), that are developed by the staff to be consistent with the monetary growth objectives selected by the FOMC-the Open Market Committee. For the most part the practical operative target is a weekly average of nonborrowed reserves over a three-week to five-week interval.

In constructing reserves paths, the staff starts with the desired short-run growth rate of money supply measures adopted by the Open Market Committee. These objectives-typically two or three months ahead-are designed to be consistent with the committee's annual targets. There is an element of committee discretion in choosing the short-run objective, even given the annual targets, as judgments can differ on how fast one should seek to return to the desired long-run path, if there had been overruns or underruns earlier.

To translate the short-run growth paths into reserve targets, one first develops monthly paths and then weekly deseasonalized path values. The total reserve path is then built up as the sum of required reserves to support the monetary path values, plus an allowance for reserves required against liabilities not in the monetary aggregates, such as interbank or treasury deposits, plus an allowance for excess reserves. The path for nonborrowed reserves, in turn, is simply the total reserve path, minus the initially assumed level of borrowing to which the committee has agreed. That level is usually placed close to recently prevailing levels of borrowing, though it could be set higher or lower if it were desired to impart some initial thrust toward some greater or lesser pressures on bank reserve positions. Actual borrowing levels, of course, can be expected to depart from the initially assumed level as monetary growth, and, hence, bank demand for reserves, exceeds or falls short of path levels. 
The translation from money supply path levels to desired reserve levels is reviewed each week and, if need be, adjusted for changes in the assumed reserve-tomoney multipliers based on more recent experience. For instance, if relatively more deposit growth is occurring at member rather than nonmember banks, compared with the earlier assumption, there would be reason to adjust the path levels of total and nonborrowed reserves to accommodate this.

Under this approach monetary growth in excess of path causes increases in borrowings from the Fed, which would be associated with higher interest rates and pressure on the banking system that would, over time, tend to return growth of money supply and reserves toward the desired paths. Shortfalls in growth would have the opposite effect, reducing the need for borrowings and thus encouraging lower interest rates and more vigorous monetary expansion.

These forces of greater or lesser borrowing can be augmented and accelerated by making adjustments in the nonborrowed reserve path, downward to enlarge borrowing and reinforce a restraining impact, or upward, to have the opposite effect, thus speeding the return of money growth rates to path. Discount rate moves can further augment these effects.

By focusing on attaining a nonborrowed reserve objective over a three-week to five-week period, the approach represents a disciplined standard for responding promptly and forcefully to significant deviations in monetary growth, while filtering out some of the volatile noise.

Since the path objective for total reserves is somehow a more fundamental underlying objective of open market policy, why not focus on that, rather than on nonborrowed reserves? The difficulty with such an approach is that total reserves are not really a practically attainable objective in the short run of a week or a few weeks. Relentless pursuit of that objective could lead to huge gyrations in financial markets and interest rates that would dwarf even the large fluctuations of the past nineteen months. If the banking system experiences a surge in deposits, it must get hold of reserves to support those deposits. After seeking out alternative sources, and in the process, pushing rates up, the banks will turn to the discount window for the needed reserves. But then if the Fed is following a total reserve target, it will immediately seek to counteract the borrowings by selling securities to absorb reserves, thus forcing rates even higher.

In the meantime, the banks would seek to borrow more, all the while pushing rates still higher, and the Fed would respond by selling more securities. You get a ratcheting effect that would be particularly severe under the present lagged reserve accounting system, although $I$ believe it would also be quite marked under contemporaneous reserve accounting, as banks would be reluctant in the short run to liquidate assets to the necessary extent.

The focus on nonborrowed rather than total reserves does not, of course, avoid interest rate effects-witness the large rate movements of the past nineteen months-but it does limit the tendencies toward extreme volatility of rates up or down that would serve chiefly to confuse the financial markets, rather than guide them along a desired track. Instead, the nonborrowed reserves approach fosters the 
application of increased or decreased pressure in a relatively deliberate, sustained fashion.

The weekly objective for nonborrowed reserves is by far the primary determinant of the Fed's day-to-day actions to add or absorb reserves.

As to the federal funds rate, I mentioned that the broad range set by the Open Market Committee is more in the nature of a checkpoint for further committee consultations than a limitation on day-to-day desk operations. Indeed it is a matter of public record that the Fed funds ranges have not been constraints on desk operations on more than a very few days in the past year, pending review by the committee. The desk also looks at rate levels as a potential source of information on the availability of reserves. Given that we have to rely on projections of technical factors affecting reserves, such as Federal Reserve float, the behavior of the market in bank reserves can sometimes be a marginal factor influencing the timing or size of an open market operation.

How well has the nonborrowed reserve target procedure worked? Well, viewed over the whole time span since October 1979, or for periods of a year, the money growth results have been pretty close to those desired. For all of 1980 , for example, the growth in the narrow money supply was 7.25 percent for MlB, just a quarter percent over the desired range, while for broader money supply measures, the overshoot was on the order of one-half to one percentage point. To be sure, monthly or even quarterly growth rates deviated significantly from path growth rates, but there is little evidence that deviations over such short periods, if reversed subsequently, have significant consequences for the economy. Rather, these variations testify as to the substantial short-run variability in the relation between money and economic activity.

On the other hand, an all out effort to produce smooth quarterly growth in the face of this changing relationship would quite likely cause very sharp gyrations in interest rates and unsettling consequences for the economy, and it would probably fail to achieve the smooth desired money supply growth to boot.

In conclusion, 1 believe that the present approach to operations provides a technique for achieving reserve growth in line with the Federal Reserve's money growth objectives, with a forceful response mechanism to return monetary growth to path when it strays off, and in a time frame that is meaningful for the economy's performance.

\section{FOR THE AFFIRMATIVE}

Allan H. Meltzer: I am going to divide my remarks into a critique of the Federal Reserve policy and a critique of their operations. The policy is what they do, the goals they pursue, and the results they achieve. The operations are the methods they use to achieve the goals that they set.

We offer three main criticisms of their policies. First, their policies produce high and variable inflation. Second, their policies produce procyclical monetary growth; 
money growth rises during periods in which the economy is expanding. addling fo inflation, and falls during recession. Illaking recessions worse and adding to unemployment. Third, their attempts to keep interest rates from rising in the past had exactly the opposite effect. Interest rates are high because the Federal Reserve produced a high and rising rate of inflation that has fed into all the interest rates in the economy, caused a devalued dollar, high inflation, and contributed to slower real growth.

My colleague, Mr. Rasche, commented on the degree to which the Federal Reserve now accepts our view that inflation can only be ended by reducing the rate of money growth, but fourteen years of inflation passed before they accepted that view. During these years the rate of money growth, the average rate of growth of the monetary base, and other monetary indicators, rose from a noninflationary level of the 1960 s to the very high inflationary levels of the present.

Let me show you a slide of what has happened to the rate of monetary growth that we want them to control, the rate of growth of the monetary base (Fig. 1). The Fed has very recently adopted our view that controlling money growth helps to stabilize the economy; but over the period shown, the three-year moving average of the growth rate of the base, which predicts the underlying rate of inflation, has moved up and stayed high, then moved up and stayed higher.

Here is Mr. Axilrod's own statement of February 25, 1981, explaining the reasons for controlling money: "If spending surges unexpectedly ... adherence to a money stock target would automatically lead to tighter financial markets, tending to offset some of the surge in spending. Similarly, if spending were to weaken unex-

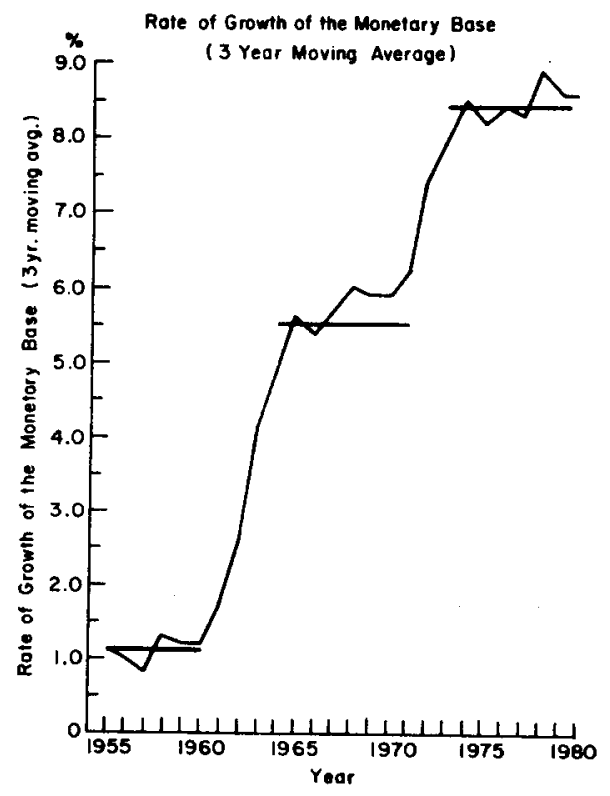

Fig. 1 
pectedly ... efforts to hold to a money target would lead automatically to lower interest rates, which would tend partially to restore spending to desired levels." Mr. Axilrod grants our second argument, an argument made repeatedly and until recently rejected by every spokesman for the Federal Reserve; it is the argument that attempts to control interest rates and the neglect of growth in money, in which they persisted, have caused bigger swings in the economy than the policies which we have recommended for fifteen or more years.

Our third criticism is that the policy failed in its main objective. Market rates of interest are dominated by inflation premiums. In March 1969, yes, 1969, the chairman of the Board of Governors of the Federal Reserve System, Mr. William McChesney Martin, testified as follows: "Over the long run, expansive monetary policies may not lower interest rates; in fact, they may raise them appreciably. This is the clear lesson of history that has been reconfirmed by the experience of the past several years. "'10 At the time, interest rates on long-term government bonds were 6 percent. Now they are 13 percent. Yet the Federal Reserve waited more than ten years after 1969 before it abandoned its efforts to control interest rates and set out to control money growth rates.

Five or six years ago the Federal Reserve took the first hesitant steps to set targets for money growth. These steps were not taken in recognition of failed policies. They were forced on the Federal Reserve by Congress, in response to complaints by many economists, including, I am pleased to say, the members of the Shadow Open Market Committee.

What has been the record of their efforts to control monetary growth? Figure 1 shows no significant change in the rate of growth of money base in the five or six years during which they have set targets for money growth. The Fed does not set targets for the base; they use other measures of money growth. Currency and checkable deposits is the one most commonly watched in the marketplace.

\begin{tabular}{|c|c|c|}
\hline \multicolumn{3}{|c|}{ Money Growth: $1975-1980$} \\
\hline \multirow[t]{2}{*}{$\begin{array}{c}\text { Period } \\
\text { Fourth Quarter }\end{array}$} & \multicolumn{2}{|c|}{$\begin{array}{l}\text { Percent Change from Fourth } \\
\text { Quarter of Previous Year }\end{array}$} \\
\hline & Target & Actual \\
\hline $\begin{array}{l}1976(\mathrm{M} 1) \\
1977(\mathrm{M} 1) \\
1978(\mathrm{M} 1) \\
1979(\mathrm{M} 1) \\
1980(\mathrm{M} 1 \mathrm{~B})\end{array}$ & $\begin{array}{l}4.5-7.5 \\
4.5-6.5 \\
4.0-6.5 \\
3.0-6.0 \\
4.0-6.5\end{array}$ & $\begin{array}{l}5.8 \\
7.9 \\
7.2 \\
5.5 \\
7.1\end{array}$ \\
\hline
\end{tabular}

Table 2 shows the record. Clearly the record is not one of high achievement. In three of the five years the Federal Reserve missed the target. Each time it missed,

\footnotetext{
"Stephen H. Axilrod, "Overview of Findings and Evaluation," in New Monetary Control Procedures, Federal Reserve Staff Study (Washington, D.C.: Board of Governors of the Federal Reserve System, February 1981), pp. A15-16

${ }^{10}$ William McChesney Martin, Statement before the Senate Banking Committee (March 25, 1969).
} 
money growth was too high, never too low. You see again in Table 2 what you saw in Figure 1. There is no sign that the commitments to achieve slower money growth have been kept. In 1980 money growth is higher than in 1976, and about the same as it was in 1978.

Late in 1979 the Federal Reserve abandoned efforts to control interest rates. Years of high inflation, slow growth, a devalued dollar, and a stagnating economy finally brought a response. But, instead of adopting the procedures to control money growth reliably, the Fed chose its own way of doing things. They didn't control the rate of growth of the monetary base, the assets on their own balance sheet. They didn't control the rate of growth of total reserves. They controlled nonborrowed reserves. What they usually say is that under prevailing institutional arrangements - that means under the rules they have fixed and which they could easily correct-total reserves are more difficult to control. Mr. Sternlight just made that argument to you. What he didn't say is that if they would eliminate the lagged reserve requirement rule and make the discount rate move with market rates, they would be able to control total reserves more reliably.

Figure 2 shows what has happened during the period in which they have controlled nonborrowed reserves. Notice the very large swings, from plus 50 percent to minus 50 percent rate of growth. These monthly rates of change have been annualized. Notice also that peaks in the rate of change of nonborrowed reserves match troughs in the rate of growth of the monetary base. The difference between the

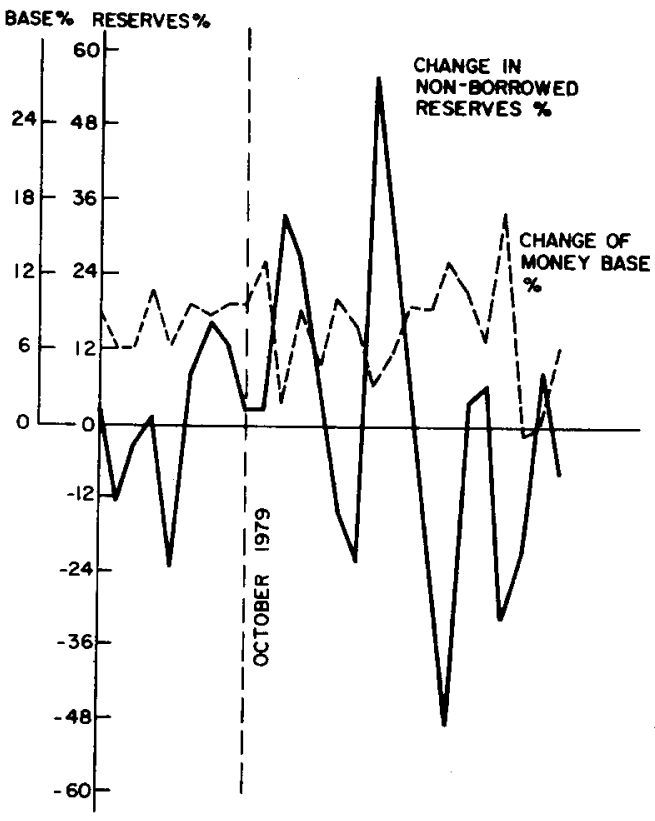

FIG. 2 
two lines is mainly bank borrowings, which the Federal Reserve has difficulty forecasting and which made their control procedures more variable than they have to be.

We, on the affirmative, believe that interest rate and monetary growth variability are higher than required; both would be reduced if the Fed eliminated the principal source of the difficulty. Why are short-term policies so unstable? The Fed estimates bank borrowing from projections of interest rates and borrowing. Their procedures increase variability and reduce control. Our studies, and studies within the Federal Reserve, by Peter Keir," reach the same conclusion. In Keir's words, a penalty discount rate would "make nonborrowed reserves virtually the same as total reserves and thus improve the desk's ability to hit its target for total reserves." This is exactly the opposite of what you heard from Peter Sternlight a moment ago, but it has been recommended by the Shadow Committee for a very long time. It is our current recommendation.

For the past fifteen years we have suffered rising inflation, increased variability, and greater instability in the American economy than we had to suffer. The Federal Reserve has tried to deal with these problems by finetuning. Their methods have made the problem worse. Although they now recognize many of their past mistakes, their performance is now no better than it was in the past. Gradually, reluctantly, but finally, the Federal Reserve has accepted many of the arguments we have made and the solutions we and others have proposed-to control money, not interest rates-and they accepted the goal we proposed-sustained reductions in money growth as the only lasting way to end inflation.

The Fed has tried its way for many years. The result is high inflation, a devalued dollar, a stagnating economy, and a loss of credibility in what was once an esteemed institution of government. Isn't it time to stop the debate, the obfuscation, and the hesitation? Isn't it time to control money by controlling the growth of the base from the supply side-eliminating self-imposed impediments such as lagged reserve requirements, inflexible discount rates, and other technical obstacles that make money growth rates higher and more variable than they have to be?

\section{FOR THE NEGATIVE}

StePhen H. Axilrod: There is quite a lot to say on this complicated subject, particularly after having heard Allan Meltzer's and Bob Rasche's eloquent statements. That lady with the ten minute sign makes it difficult to keep to the thoughts I had earlier and also to add some others. Maybe I should just shout "No! No!" for some of the things I can't get to.

I would like to approach this a little bit in the spirit Bill Dewald mentioned at the beginning. I think my job here is the very unpleasant one of exposing you to the facts, including the results of our recent study of the Fed's new reserve operating procedure-all in the spirit of the scientific endeavor Bill mentioned.

\footnotetext{
"Peter Keir. "Impact of Discount Policy Procedures in the Effectiveness of Reserve Targeting," in New Monefary Control Procedures, p. 8.
} 
I might describe the results of our study ${ }^{12}$ for you, under four headings, time permitting. One is what we found about money supply volatility; another is what we found about the possible limits to the precision of monetary control; another is about interest rate volatility; and the fourth is the sensitivity of GNP to money supply volatility. When I say "volatility" I am really talking in a fairly short-run framework. I am talking about what you would expect month by month, quarter by quarter, in the process of trying to control money over a one-year time span to meet the kind of targets that the Federal Reserve has set for itself.

Now, the study's work has been done by a large number of people, and I will not be able to give credit to all of them as I am talking, so please bear in mind that there are others who deserve credit for this, or whatever else Allan Meltzer is apportioning.

In any event, we found that weekly you can expect the money supply, say, narrowly defined money MIB, to vary in a range of plus or minus 3.3 billion dollars two-thirds of the time from sheer noise, that is random, up and down, fluctuations and difficulties of seasonal adjustment. All you Fed watchers out there bear that in mind. Now that is two thirds of the time; if you want to be sure about how much is noise, say 95 percent of the time, it would vary 6.6 billion dollars. So just bear it in mind more carefully.

On a monthly basis, the money supply also varies substantially from the noise that comes essentially from the fact we have a trillion dollar economy. Money goes through banks continuously. Sometimes the treasurer of a corporation is late for work, and sometimes he takes a day off, or his assistant is sluggish. The money stays in the bank too long; then it gets quickly withdrawn. Substantial variability results. On a monthly basis you can expect noise in the order of plus or minus 4.5 percent at an annual rate, using data from 1973 to 1979. That is two-thirds of the time; you can double it at the $\mathbf{9 5}$ percent level.

Last year we had a little more volatility monthly than that. I am sure that the lady counting the minutes is going to get to "stop" well before I explain all the reasons. But, believe me, my explanation would be that it wasn't because of the control procedures we had instituted; it was because of the economy, which was subject to a large number of unusual outside disturbances last year. We had credit controls, and many other exogenous factors impinged on the economy, so that you had an experience different from the average of the preceding years.

Finally on the question of volatility, I ought to point out that foreign countries experience even greater volatility of money than we do. Thus, in our case even the degree of variability last year was well within the range of foreign experience.

Now, with regard to the precision of control, I think Bob Rasche has made the point that I was going to make, that you can't be very precise in the very short run, say a month or even two. Our study demonstrated that. Virtually regardless of the control procedure used, nonborrowed reserves, the base, or what have you, you miss your money supply target in a range of plus 8 to 10 percent monthly. So you

12Federal Reserve, New Monetary Control Procedures. 
expect those large variations and, as Bob says, they tend to average out. The results are much better over a longer-run period. The lesson from that is to be patient. Thus, you in the market don't have to write every week that money was too high or tor) low. You will undoubtedly be wrong a month or two later when the averaging process works its way through. Our study did not suggest that monetary control could be improved, given existing institutional arrangements, under a total reserves or total base target as compared with our present procedure involving a day-to-day nonborrowed reserve path and total reserve guideline.

The reasons for this are important to understand, and, again, I am sorry there is literally not time for an adequate explanation. But, if all of you had money and banking courses, and I trust you have had them, you know there are varying reserve requirements set by law on various kinds of deposits. When the public shifts its deposits among the various classes of deposits, something the public controls-we don't-it changes what can be called the "reserve multiplier." Changes in the multiplier, when you are adhering to a total reserve target, will make for deviations, sometimes substantial, between targeted money and actual money.

While we do establish a total reserves path as a general guide, on a day-to-day basis operations are designed to hit a nonborrowed reserves target, which can be adjusted up or down over time to offset variations in total reserves caused by undesired movements in money. However, in the short-run adherence to nonborrowed reserves does permit variations in borrowing by banks to cushion an undesired effect on money from changes in the deposit to reserves multiplier. If the deposit mix changes so that a given level of total reserves would produce less money than desired, borrowing (and total reserves) could expand under a nonborrowed reserves target to produce the desired amount of money. Thus nonborrowed reserves are advantageous when unexpected shifts are occurring from the supply-of-money side, in contrast to the demand side.

There is the risk that problems may not be caused by supply-side multiplier variations, but that borrowing may be running strong, say, because demand is expanding. In these circumstances, though, one certainly could and should lower the nonborrowed path as 1 mentioned earlier. It is also true that if one changed the institutional environment, one would have a better shot at attaining a money objective through control of the total reserves-because the risk of error through unexpected multiplier variations would be reduced. The institutional environment is in the process of change as we move toward somewhat more uniform reserve requirements under the Monetary Control Act, but we have got eight years before that is fully phased in and sixteen years if you are in Hawaii. It should be noted that while uniform reserve requirements on the deposits you want to control would tend to make it more efficacious to target a total rather than a nonborrowed reserve aggregate, it would not necessarily make the monetary base a better choice than total reserves. The reason is that there still would be a 100 percent reserve requirement on currency and a fractional requirement on deposits. As a result there would be more multiplier distortions from adhering to the base (currency plus reserves) than from adhering to total reserves. 
I am rushing, I am afraid, since time is running out. But you may well ask: If this money supply volatility is inherent in the financial system as you, Mr. Axilrod, are trying to tell us, over how long a period should money be averaged to determine whether its behavior is significant? We tried to evaluate that by seeing how sensitive nominal GNP was to movements in money above or below paths for three months or six months. Summarizing very generally, our results are that it is not very sensitive. If you are off path for a quarter, indeed two quarters, and get back on subsequently, you are hard pressed to see any effects on nominal GNP.

We ran this with a large-scale quarterly econometric model. We also ran it with monetarist models that the St. Louis Federal Reserve has, and one from the Kansas City Fed. These models were a bit more sensitive to money variations. Still undershoots compensated for overshoots, and vice versa, so that in the end, or indeed even in the process, it didn't make much difference if one was off target for three to six months or so, so long as you got back on in the ensuing three or six months.

When you get off path for the monetary aggregates, you do of course have the problem of deciding how fast to get back on. Our results were the faster you get back on, the more interest rate volatility you get. It is not very informative simply to say that interest rate volatility is bad, but in practice there are people in financial markets who get upset when interest rates go down and up frequently, and you can get adverse psychological reactions to that.

In our study we tried to see how fast one can get back on the path for the aggregates, while minimizing, as it were, interest rate disturbances. It looked like three months would be a good time to aim at getting back. You would still have considerable interest rate volatility, but there would be much more if you tried to get back faster, or instantaneously, that is, if you were never off. So it looked from our research that three months was a reasonable time period for trying to get back on path.

\section{CROSS-EXAMINATION}

AxILRoD: I would like to ask either Professor Meltzer or Professor Rasche their feelings about money stock volatility, let's say M1B or whatever you believe should be controlled extremely precisely. If your long-run goal is, say, 5.5 percent annual rate of growth - or choose any number-what would you expect, per month? Would you expect 5.5 per month, 10, zero? Given the knowledge of your own research and analysis, how do you feel one should look at the volatility question?

RASCHE: Given our knowledge of your staff's pursuits and given our own research, we think those studies suggest that if you had a target of say 5.5 percent per year, a consistent application of our procedure could easily keep the observed growth rate within plus or minus 1 percent of that number, on an annual average basis. Quarterly we would certainly expect that the deviations around a path of 5.5 percent per year would be wider than that; on a monthly basis they would be even wider. On a weekly basis they would be even wider, and if you were to publish daily 
money numbers, which I am certainly not advocating, the deviations would be horrendous.

MELTZER: I would add one thing. They would be narrower than they have been. We would like to ask a question. It is a fundamental question from the standpoint of this debate. We have urged, along with many other people, that there be more flexibility in the discount rate. In October 1979, you announced there was going to be more flexibility-not you personally, but your institution. That was eighteen months ago. The studies by Keir, ${ }^{13}$ done within the Federal Reserve System, show that if we got rid of the lagged reserved requirements and did have a more flexible discount rate, then money growth would be less variable; your control procedure would be less variable; your credibility would be higher.

Why is it that at the end of eighteen months no step has been taken, as far as we know, to implement the procedure which was once announced and the procedure which has been widely recommended by, I think, economists of all types, monetarist and nonmonetarist, market and just general? That is our question.

AxILROD: I understand the question very well. I would note in the course of last year the Fed did impose a surcharge rate above the basic discount rate, which was an innovation. We still have one at present. The basic discount rate is 13; the surcharge rate is 16. When the surcharge was first imposed, it was a penalty. Then, of course, market rates rose for awhile, and it wasn't a penalty for awhile. But one of the innovations made since the procedures were implemented was to work with a surcharge on the basic discount rate. How developments will evolve from that, I am not in any position to foretell or announce if I did know.

Secondly I would like to take the opportunity of answering Allan's question to make clear something about the discount window which was implicit in my comments. Access to the window is both "a good" and "a bad. "It is a good, as I tried to mention before, when your multiplier estimates are wrong; you don't catch changes in them fast enough. We try to keep up with them; we have an estimated multiplier, and if it turns out to be wrong, we try to change the reserves to be more consistent, try to catch up with them. Sometimes you don't, you can't, and the discount window serves as a buffer. If, for a given level of deposits that you are happy with, that are on target, banks need more required reserves than were built into the reserve path, then the discount window can provide those.

Now that is the good. When it is performing that "good" function-I am trying to use words that are simple-I mean informative. I don't mean good and bad in value judgment terms. When the discount window is performing that good function, there is no particular reason to move the discount rate. Now, on the other hand, it may be that our Mr. Sternlight is providing nonborrowed reserves as called for by the path, but that borrowing is going up a lot, not because you are on the money target but because you are off the money target. That is the case Allan Meltzer is

${ }^{13}$ Keir, “Discount Policy Procedures," p. 8. 
justifiably concerned with. There you would exercise, obviously, closer control if you raised the discount rate more promptly. And if you had it automatically tied to market rates, it would tend to go up pretty much without your making a decision.

But even so, there are matters of judgment involved. It is not as "simple" at that; and I use simple in quotes because I would in no way want to suggest Allan is being simple. But, because of the variations in money demand I earlier noted-money may grow on its own 10 percent this month and zero next month-policymakers necessarily tend to be rather cautious in approaching the discount rate. They say, "Well, we have had this big increase in money and borrowing has gone up." When borrowing goes up, interest rates go up and there may be some possibility money growth will come down. We know there is a lot of randomness. We know as interest rates go up banks make adjustments. So one decision could be, we have reason to think, looking at everything, that we shouldn't raise the discount rate at this point. One alternative would be to tell Mr. Sternlight to provide even less reserves. That has somewhat of the same affect. But, what I want to stress is that when you have these sharp variations in money growth inherent in the financial system, there is some reason for policymakers to come to the judgment that they want to evaluate things as they unfold, rather than to tie themselves into possible automatic ratcheting upward of interest rates or ratcheting down of interest rates, which might develop out of a tied discount rate.

Sternlight: Professor Rasche mentioned in his recommendations that the Fed should focus on just one monetary aggregate, say MlB, and key off of that in developing its control of the aggregates and of the economy. Would he have some concern, particularly at a time like this, with focussing on just one single aggregate, MIB, when there are so many questions about its significance in view of a major institutional change currently taking place with something like NOW accounts?

RASCHE: The major institutional change that is going on now, like many major institutional changes that have gone on in the past, is caused by the current set of institutional constraints that, as part of our proposal, we advocate eliminating. In many cases the differences in the short-run behavior of various M's that we have observed in the past have been due to the Regulation $Q$ ceilings or, in more recent times, the ability of the innovation in the financial system to get around those regulatory constraints and ultimately, like at the present, the situation where the regulatory constraints have to be abandoned.

In the long run there is a strong tendency for all the aggregates to be highly correlated with one another. We don't see the very short run changes like we have perhaps seen in the last couple months as a matter of concern for the long-run strategy we are advocating. Focusing on one aggregate would not necessarily cause major problems.

Meltzer: I would like to add to the answer Bob Rasche gave. The procedure we have recommended to you, forecasting the multipliers the way we do, by compo- 
nents, produces a set of estimates for any measured set of money that people conventionally use. Each of the measures will be consistent with each of the others. If you or someone else wants to watch a broad $M$, they will have the same information that we would have from watching another, narrower $M$; that is a benefit of the procedure we recommend to you. Much of the discussion that has gone on interminably about which $\mathbf{M}$ should be controlled, is misguided. Much of that discussion could be put aside because all of the M's can be predicted in a consistent way. For short periods of time, the forecasts are consistent, and over long periods of time, the $M$ 's move in roughly consistent ways.

\section{QUESTIONS FROM THE AUDIENCE}

Question for the affirmative: What is the expected interest rate volatility under the multiplier base procedure and the consequences of such volatility?

RASCHE: Clearly interest rate volatility under any reserve aggregate approach to monetary control will be larger than the interest rate volatility that we observed before October 1979, when the Fed was working on a Federal funds rate control procedure. We have had evidence of increased volatility in the last year; things such as lagged reserve accounting and so forth add to the interest rate volatility under such control reserve procedures above and beyond what we would see in the absence of such institutions. Exactly how much volatility we would get is a very difficult question to answer.

The base of information upon which we have to make judgments about interest rate volatility comes from econometric models. Those models tend to produce interest rate volatilities that look scary, but the particular characteristics of most of those models in historical simulations is that they tend to forecast interest rate series which show much more volatility than the actual interest rate volatility that was observed over the historical period. Something is going on. The models do not have adequate specifications to account for all of the mechanisms at work on interest rates and in many cases interest rates are forced to be a buffer, to absorb shocks when other things in the real economy actually would absorb those shocks.

I might say that to the extent we have a well-defined monetary target, and thus the markets understand what the Federal Reserve is trying to do, there is a good chance that we would in fact see reduced interest rate volatility below the kind of thing we have seen in the last year. I think even the Federal Reserve staff studies, and I may be reading them wrong, would concede that a major source of volatility over the course of the last year was not the new procedures per se, but the rather traumatic experience that credit markets had with things such as the Credit Control Act, instituted in March; its repeal in June; and the uncertainty about whether it would be repealed or not.

AxILROD: I would agree with that. 
Question for the negative: Regardless of the method, why not lower the annual targets for MIB growth? The past five years indicate that the Federal Reserve's policies have fueled inflation.

Sternlight: Well, The Federal Reserve has expressed, as its long-term objective, the lowering of those growth rates, and the growth rate adopted for this year is indeed somewhat lower than the objective that was in place last year. This year's objective is also lower than the rate that was actually achieved last year, which as I mentioned was a shade over the objective during 1980. I might make another related point, if I may, with a further comment on one of Professor Meltzer's tables that showed 1980 performance. As I mentioned, MlB growth during 1980 came out just a hair over the objective range for that year, but if you were to extend for one more quarter the 1980 growth rate cone in which those targets are usually displayed, you would find that in the first quarter of 1981 , M1B had come down pretty nicely inside that desired range of growth. As we have commented, and I am not sure that the other side would disagree, quarter-to-quarter variation does occur, and it doesn't matter all that much as long as deviations from path don't persist in the same direction, getting one further off course.

You can always look back at past periods and say we ought to have been more forceful in meeting targets or set lower targets, so I think in some sense, viewing the past record one could envisage that lower targets could or should have been set in some of the recent years. I think one of the reasons we changed to the technique adopted since October of 1979 is that the Federal Reserve was not fully satisfied-in fact was far from satisfied-with the performance of earlier years. We think we have an approach that does represent a much more responsive or assured way of reaching our objectives.

Question for the affirmative: Professor Rasche mentioned in his remarks that his primary focus is still on the long-range growth. I understand that to be consistent with monetarist views generally. Given that the monetarist position has always worried more about annual trend rates of money growth, why is there so much emphasis now on the very short run aspects of money control, as long as you concede the Fed might be able to meet its long-run objectives?

MELTZER: I thought you would never ask.

The answer is we don't care about what happens from month-to-month except insofar as it has a disruptive influence. The reason it currently has a disruptive influence is that the Federal Reserve has sacrificed the very large amount of credibility it once had. It sacrificed credibility because it hasn't met its targets.

Mr. Sternlight said if you extend the 1980 data one more month we would have had 7 percent money growth. There are many ways one can hit a 7 percent target. One might be to have 14 percent for six months and zero percent for six months. When that happens people look at the 14 percent and say, maybe the inflation rate will go up. They begin to build more expected inflation into market prices and into 
what they think will happen to the long-term bond markets, prices of real assets, land, and other things. Mortgage rates and other rates begin to rise in response.

The Federal Reserve says, we can't find real effects of variability. The reason they can 't find the real effects is that their model-not just theirs, ours or anybody'scan't handle short-term changes in expectations. All you have to do is watch the marketplace. You see that interest rates are moving. People are borrowing, lending, and investing at the rates which occur. We know somebody is paying those prices and somebody must be experiencing gains and losses as a result of the volatility.

The fact that we haven't been able to find effects in the models may tell us a great deal more about the models than it does about the economy. We know when rates move up, for example, as they did last year, that somebody, somewhere is paying a 21 percent interest rate. People defer their housing and durables purchases. Other things happen. There are real effects in the economy. I don't think I have to belabor the point.

Now, if the Fed had credibility, if you knew when they said we are going to have 6 percent that their procedures were capable of achieving 6 percent and they would in fact achieve 6 percent, you would say the spurt is an aberration; I am not going to base my actions on that; I will not offer to sell a bond at 21 percent because I know that rate is not going to last; therefore, changes would be smoothed out in the market.

The reason we are concerned is because we believe the credibility issue is very important. Once they re-establish their credibility, and we believe our procedure would re-establish their credibility, then the variability in money growth from month to month would be far less important than it currently is. The evidence shows that in the countries that have greater credibility, monetary policies can produce very large swings in money growth with less effect on the economy than we have. That is the reason why we think short-term variation is important currently. We think the lack of credibility has made it important. That is why we are concerned about procedures. We believe our procedures will enhance credibility and make clear that the Federal Reserve will achieve the goals we all agree upon.

Question for the negative: Why doesn't the Federal Open Market Committee communicate more often and more precisely exactly what its reserve-targets are between the periods of the Open Market Committee meetings?

AxILROD: Well, I think you have to ask the prior question. The Open Market Committee meets and establishes money supply paths related to its long-run targets at each meeting, and those are short-run paths because you have a meeting about every month and a half or so. It doesn't communicate those paths, of course, until after the next meeting.

So I think the question isn't so much why don't you put out reserves paths, but why don't you put out the short-run money target, the thing you are aiming at. The Open Market Committee has thought that announcing its targets for the interval between committee meetings would lead quite probably, though it is difficult to prove this one way or another, to even more erratic reports in markets and to even 
more erratic market behavior by people who make a living watching the money supply than does the present procedure.

That is judgmental and I think there are going to be people who disagree one way or another with that forever and ever. It is essentially a judgment about what is the most effective way to conduct policy. We do announce the long-run targets twice a year; that is the basic target at which you are aiming.

Question for the negative: At the present time the Federal Reserve publishes interest rate targets which it says it does not follow, but does not publish reserve targets which it does follow. Can you explain that anomaly?

AxILROD: Well, we publish the basic money supply target for the year. At the same time there is what you call an interest rate target, but what is really a band for the federal funds rate that sets consultation points for the open market committee. The federal funds rate band is published with a lag at the same time we publish the short-run money supply target covering the period between committee meetings. So those things are published at the same time. It isn't that we don't publish the basic money supply path guiding the committee.

The federal funds rate ranges are established by the committee at the same time the committee sets the short-run money supply targets. In setting the range, there is no thought that the federal funds rate will be in the high or low end of it. The funds rate is free to move within that range. When it gets to the upper limit of that range, it is even free to go above it, and similarly for the lower limit. However, if it looks as if it is going to go above or below it in some persistent way, then the committee has to be consulted as part of normal, good operating procedures.

When the committee is consulted-as it should be because substantial changes in credit conditions affect housing and other elements that make this economy go-it makes a fundamental decision about whether to let the rate go or not let it go in meeting its reserve and money objectives over the short run. The conclusion is normally, "Let it go."

I hope that is an answer to your question. That is how I perceive it.

Question for the affirmative: Why has monetarism not worked well in the United Kingdom?

MELTZER: It is working. Let me say I hope we have as much success in bringing down the rate of inflation as the British have had. They have reduced the rate of inflation, measured by conventional methods, which are not very accurate, from 22 percent to 8 or 9 percent. Measured by more accurate methods, probably from 16 percent to 9 or 10 percent. That is a substantial reduction in one and a half years. It has been accomplished by reducing the growth of the base, the only way inflation can be reduced.

The cost has been high, partly because the tax cut stimulated saving and Mrs. Thatcher, despite her promise, and contrary to her intention, was unable to cut 
public spending. The result is that most of the increase in saving went into financing the budget deficit and not into new expansion of the economy.

Fortunately, under the Reagan administration's proposal, we are not likely to have the same problem.

Much of the unemployment in Britain has nothing to do with Thatcher's policy, in any direct sense. For many years people were unemployed, but no one knew it. They were hidden away in British Leyland, British Steel, British Airways. These firms were subsidized in part to hide unemployment, to keep workers in the labor force. Mrs. Thatcher took away some of the subsidies, so the workers are now counted as unemployed.

The British economy, as we expected, is beginning to turn around. Full recovery will not be easy to achieve. But to say monetarism isn't working is the very opposite of the truth. The rate of inflation has been brought down; rates of wage increases have been brought down; the public sector budget has not been controlled; the economy continues to have some problems.

We who work on the Shadow Open Market Committee have never said that inflation will be ended at zero cost. All we can offer is a way to reduce the rate of inflation at lowest cost. We have always tried to emphasize that those costs are not absolutely low, and we have emphasized that we believe a recession is likely.

Question for the negative: When the Fed overshoots the targets, in any one year, it builds that excess into next year's growth. Shouldn't the committee not only lower the targets each year, but use some sort of lower adjusted base to avoid base drift?

AxILROD: If the money supply is off target in year one, why do you start from where it ended? Why don't you make up for that overshoot in year two? The answer depends on where you want to start. We have always had overshoots and undershoots.

It is where you start that is important. What we do, in effect, is reinitialize the existing situation every year. You take as given the whole past and you also have your expectations of what is likely to happen to the economy in the future, given the past. You have in light of all that some view about how fast you can effectively and practically lower the rate of inflation and lower the rate of growth in money, which becomes a practical policy judgment. With MIB last year having grown only onequarter of a percent, properly viewed, above its path, should that be taken as an overshoot? The Fed did lower the path one-half percent. It would not seem reasonable to me to lower the path by one and three-quarters or two percentage points to make up for the fact that you were around the upper end rather than the mid-point of the previous year's range.

The past is done with. You have to deal with the existing situation in the most effective way. Is the most effective way to make up all at once for ten or twelve or more years of so-called "mistakes," if they are mistakes, or is the most effective way to start off this year from where you are and try to take what you think is the most practical and effective approach to controlling inflation? 
Question for the affirmative: Since the Fed has repeatedly made promises regarding the termination of lagged reserve requirements and the freeing of the discount rate and has, over the last several years, postponed or broken those promises, can the Fed be trusted, and, given the resistance we have seen this afternoon to those changes, can they be relied upon voluntarily to make any improvements at all in their operating procedures?

Meltzer: The answer is no. We have a proposal. Let me direct it to our moderator, Congressman Wylie, since he is a relevant person involved: The Shadow Committee believes that there must be greater accountability. The pressure working on the Federal Reserve to do the wrong things are as strong as the pressures to do the right thing; consequently, we need some counterweight. Let the Fed set their own targets, within the range of error we and they acknowledge to be feasible, 1 percent a year. We recommend that the Congress pass a law which says that if they don't meet their targets, by whatever means they choose to meet the targets, that the governors would offer their resignations to the president, who is ultimately responsible for the conduct of monetary policy, because he and the Congress have responsibility for the rate of inflation and the condition of the economy.

We urge that hearings be held to see whether this or some other feasible means of disciplining them be imposed. We want to force them to achieve the targets which they announce and to institute procedures capable of achieving the targets. We have had inflation, broken promises about improvement in operations for much too long. We now ought to get the best policy and the best policy procedures that the Federal Reserve is capable of delivering. If they can't deliver the policies to end inflation, we ought to get a different Federal Reserve that can.

\section{NEGATIVE SUMMARY STATEMENTS}

STERNLIGHT: We have had a number of issues pointed up here today. I can agree with a lot of what both speakers on the affirmative side have set out as the objectives, and indeed I think Professor Rasche started out observing that we do agree on the objectives. There is the overriding importance of controlling inflation, and the overriding importance of winding down the rate of monetary growth. I think we may have some differences on the importance of some particular procedures. I think the procedure that Professor Rasche was outlining, as I understand it, was tested out as a part of the studies that Steve Axilrod referred to, and it didn't really show up as significantly better, if better at all, than the types of reserve targeting we are engaged in.

Certainly the credibility factor is important. I would be disturbed, and I am sure everybody in the Fed would be disturbed, with six months of 14 percent growth, to cite Professor Meltzer's example. I am not sure which measure he referred to, whether it was the base or narrow money supply. I am very confident that under our present procedures, if you were getting growth month after month that was substan- 
tially beyond the Open Market Committee's desired rates of growth, a very strong, increasingly strong, response would be set up.

I think last year is illustrative of that kind of result. We had slow growth during the spring months, with much of the slowdown caused by the credit restraint program that was instituted in March of 1980 . Then we had a speed up that was welcome at first, because it was getting monetary growth back to the desired track. But then as it proceeded further and growth began to be excessive, the strength of the Fed's response increased in intensity. We wound up the year, as a couple of us have mentioned, a shade over target, but by the first quarter of 1981 we showed monetary growth that was well within the path growth lines extended from 1980 and if you are looking at the narrow money supply, growth was actually relatively low against the path that had just been stated as the objective for 1981 .

My point is that we have a procedure that does give forceful responses. I think that the Federal Reserve's credibility is in process of being strengthened by the sort of reactions that we are getting in the financial markets and, over time, in the subsequent rates of monetary growth. I will cede my remaining minutes to Mr. Axilrod to comment further.

AXILROD: I would like to make a couple of points. One is I would hope that our study, ${ }^{14}$ which $I$ hasten to add to all students is available free from the Federal Reserve, all six hundred pages of it, deals in considerable depth with the issues that we have been discussing-issues involved in judging what is the best method to control money. It didn't deal with whether you should control, or what measure of money should be controlled, but the best method for control. We tried to present the relevant empirical evidence as far as we could. We have exposed the study to academic and market economists. ${ }^{*}$ We have used the work done by Allan Meltzer and Bob Rasche, and I hope we have moved this debate on to a more empirical plane. Here is the evidence, let us examine it, find the best way to control money in light of the evidence and whatever institutional reforms may seem necessary-given what appears to be an inherent volatility of money in the economy, but also of course given the need over a longer run, over some reasonable length of time, to assure control.

I agree very much with Allan that curbing inflationary expectations is extremely important if present policies are to be successful. Those expectations are based in part upon monetary policy. But they are also based, Mr. Congressman, on budget policies; they are based too upon what people think OPEC is going to do; and for those who follow futures markets, you can see expectations are also based upon the weather forecasts.

I don't want to underestimate the impact of money variations on expectations. It is quite possible that they have an effect, but let me make the world a little more complicated for you. Think back to the second quarter of last year. As Bob Rasche

\footnotetext{
${ }^{14}$ Federal Reserve, New Monetary Control Procedures.

*See Stephen M. Goldfeld's review of the study in this issue, pp. 148-55.
} 
mentioned, the Credit Control Program came into effect and in consequence, we had a really sharp drop in interest rates and a very sharp drop in spending, because the public came to believe that you shouldn't borrow at all. The Credit Control Program was in fact a limited program, but it was interpreted very broadly. Everybody stopped spending. My favorite story in that respect is about the people in the recreational vehicle industry who came in and showed us their order books. About a week after the Credit Control Program came into effect, their order books dropped to here [gesturing]. The second week they were down to here, and so forth. It was just absolutely spectacular, and those particular vehicles were in fact exempt from the reserve requirement on credit. So the program was interpreted rather more broadly by the public. In consequence, interest rates dropped sharply; people paid off debts; and money supply dropped sharply. Thus we had sharp variations in both money supply and interest rates. The Credit Control Program was the exogenous event triggering the sharpness of these variations. They were not a product of the monetary control procedures.

There were two reactions to the variations in money and interest rates. Half the people told us, "Money supply is dropping in April and May and you are being deflationary. It has got to stop." The other half of the market told us, "Interest rates are dropping like crazy. They are well below any reasonable expectation of the long-run rate of inflation; therefore, you are being highly inflationary."

I think there is legitimate question as to which variation-in money supply or in interest rates-was in that particular set of circumstances having a bigger effect on market psychology and the psychology of the decision makers. In many ways of course the important decision makers are you as a consumer, you as a businessman, you as an employee demanding wage increases. 1 think the second quarter of last year brought home to all of us the difficulties in interpreting factors that affect the psychology of decision makers.

When Bill Dewald opened this discussion of monetary control, he called it, and billed it as, a debate. I kept wondering what we were debating about. We have been talking for a long time, and maybe if I took Allan's place, I would say the same things he said. If he took my place he might have said what I said. He is shaking his head, but I would be too if he were saying it.

Still, I would like to think we have a certain convergence in the sense we are all working empirically; we are trying to find the best thing to do, what affects psychology and what is the best method of monetary control.

\section{AFFIRMATIVE SUMMARY STATEMENTS}

RASCHE: First in response to Mr. Sternlight's comment, we would like to make it clear that as far as we are concerned, our procedure has not been tested. All the experiments conducted in the study recently concluded by the Federal Reserve Board staff were conducted under the present institutional setting. To that extent we don't feel they adequately represent the kind of behavior that would necessarily appear under the regime we would like to see. Second, our procedure has not been 
tested since October 1979. Mr. Sternlight himself said earlier this afternoon that under the current circumstances the Federal Reserve does not necessarily seek to return to the long-range targets immediately subsequent to some sort of shock to money growth.

Now, the rationale for not implementing the kind of procedure that we seek is the alleged high cost of interest rate variability. The question is what are these high costs? The study that was just concluded by the Federal Reserve staff, which in many respects is a very, very competent study, was done very thoroughly in terms of its search for cost of interest rate variability. We all concede, I think, that interest rate variability has gone up dramatically since October 1979. All of us would agree that the increase is not totally due to the implementation of the procedures that were begun in October 1979. Nevertheless, the variability exists.

The staff searched under every big rock they could find, and little rocks I didn't think they could find, and if $I$ am interpreting their conclusions correctly, they didn't find high costs of interest rate variability; indeed they were hard pressed to find small costs of interest rate variability.

To repeat, we are not primarily concerned with random short-run fluctuations in money growth, so long as they do not become systematic. Indeed we are prepared to acknowledge that nonsystematic "noise" in short-run money growth rates would occur under the kind of procedures we are arguing for. The problem is that there is a lack of gravitational law at work under the present circumstances and procedures. What goes up has a tendency to stay up, and what goes down frequently comes up very fast. Short-run variations tend to be converted into very systematic long-run variations, which tend toward the high end of the Federal Reserve's range or, more often than not, above the Federal Reserve's ranges. This has led to the credibility problem which the Federal Reserve has at present.

I guess I would like to close by quoting to you from the assumptions that are presently being made by the agency which is in charge of providing the economic analysis to our moderator, as he prepares to vote on various budget issues. The recently completed study on economic policy and outlook for the economy from the Congressional Budget Office for March 1981 says, and I quote: "In addition, growth in monetary aggregates over the next two years is assumed to be somewhat above the Federal Reserve's announced target ranges. The economy is expected to encounter persistent inflation and high nominal demands that will make it difficult for the Federal Reserve to achieve its announced targets without a significant increase in unemployment. ${ }^{15}$

On the credibility issue, if even the CBO doesn't believe the Fed, the Fed clearly has a problem.

To repeat, one of our major reasons for advocating this proposition is to over-

${ }^{15}$ Congressional Budget Office, Economic Policy and the Outlook for the Economy, March 1981.

That the Federal Reserve's credibility is presently very low is witnessed by the following operational assumption of the Congressional Budget Office for current policy analysis: "In addition, growth in monetary aggregates over the next two years is assumed to be somewhat above the Federal Reserve's announced target ranges. The economy is expected to encounter persistent inflation and high nominal demands that will make it difficult for the Federal Reserve to achieve its announced targets without a significant increase in unemployment." 
come this problem, to restore credibility to the Federal Reserve System and make life easier for them, as well as us.

Meltzer: I want to begin by thanking Bill Dewald for arranging this discussion, Congressman Wylie for chairing it, but most of all, I want to thank Peter Sternlight and Stephen Axilrod for coming and participating in the discussion with us.

I would like to close by quoting the president: "We must develop a monetary policy that will rationally control the money supply." That means he shares our view that there isn't one now.

We have offered a set of proposals that we believe accomplish the president's goal, our goal, the goal we all share. We have argued for years that inflation is costly and destructive. Recent estimates sugget that the loss in the economy from inflation is currently about 80 billion dollars. Virtually every one now shares these views that were once heretical. Normally the kinds of issues we are discussing, procedural issues that may be considered arcane, are best left to be argued in academic seminars. But it is the procedural issues that must be resolved if monetary policy is to do better. Our case is simple: money growth targets have not been met; consequently, inflation is deeply entrenched in the economy and the Federal Reserve lacks the credibility to achieve slower inflation at lowest cost.

We on the Shadow Committee want to end inflation at lowest cost. We don't believe it will be easy, but we believe that the procedures by which money growth targets are achieved can be improved. The improvements lower the cost.

We believe that if the Federal Reserve is to control money growth, they will end up doing it our way, or something very close to our way, that they will eventually concede the point of this debate.

The purpose of this discussion or debate is to hasten that time. Their research shows, as they have emphasized, that all the procedures are the same, but as they usually say, "under current operating procedures." That means under the rules by which they are operating. Those rules are self-imposed. We want to change those rules. Their own research, by Keir and others we have mentioned and by virtually every academic economist who has studied this, supports our view. Our ideas have found their way into the marketplace, into the press, to governments here and in foreign countries. The Swiss are able to control money growth rates with high variability, but with strong belief that when they announce a target, it is going to be achieved. Their experience could be duplicated here. It is not the variability, it is the credibility of the policy that is important.

Bob Rasche and I have quoted mainly from Federal Reserve sources, not because it is the only source available-it isn't-but it is noncontroversial. Their research tells them what we have tried to tell them. I would like to quote from a different source, Treasury Undersecretary Sprinkel, testifying before Congress earlier this month. He said, "We believe the Federal Reserve's control mechanism would be improved if the interest rate constraints were removed completely and efforts were concentrated on controlling the adjusted monetary base or adjusted bank reserves. Adoption of contemporaneous reserve accounting and a flexibly oriented discount 
policy would also help the Federal Reserve match their actions with their policy and thereby restore credibility to anti-inflation efforts. Avoidance of extreme monetary variability is also necessary if policy direction is to be believed. A steady but persistent decline in monetary growth over the next four years will promote stable economic growth, declining inflation, and stable but lower interest rates. "16

I want to close by again thanking the members of the negative for sharing their views and responding to our criticisms. We wish them well.

Thank you.

${ }^{16}$ Beryl W. Sprinkel, Statement before the Monetary and Fiscal Subcommittee of the Joint Economic Committee (April 8, 1981), p. 12. 
917. An Economics Approach to Modeling the Productivity of Computer Systems. Charles H. Kriebel and Artur Raviv.

918. Adjacent Vertices of the All 0-1 Programming Polytope. Egon Balas and Manfred W. Padberg.

920. Estimation of the Correlation Coefficient from a Broken Random Sample. Morris $H$. DeGroot and Prem K. Gool.

922. A Parametric Linear Complementarity Technique for Optimal Portfolio Selection with a Risk-free Asset. Jong-Shi Pang.

923. An Algorithm for Large Zero-One Knapsack Problems. Egon Balas and Eitan Zemel.

924. A Parametric Linear Complementarity Technique for the Computation of Equilibrium Prices in a Single Commodity Spatial Model. Jong-Shi Pang and Patrick S. C. Lee.

925. Should Accounting Standards be Set in the Public or Prlvate Sector? Robert S. Kaplan.

926. A Competitive Theory of Fluctuations and the Feasibility and Desirability of Stabilization Policy. Finn Kydland and Edward C. Prescott.

927. Models of Money with Spatially Separated Agents. Robert M. Townsend.

928. The Limitations of Log-Linear Analysis. Howard Rosenthal.

929. Dynamic Effects of Government Policles in an Open Economy. Robert J. Hodrick.

930. A Cost Operator Approach to Multistage Location-Allocation. Robert V. Nagelhout and Gerald L. Thompson.

931. An Actlvity Analysis Approach to Unit Costing with Multiple Interactive Products. Hiroyuki Itami and Robert S. Kaplan.

932. A Dimension of the Myths and Science of Accounting. Robert S. Kaplan.

933. Dlscrete Programming. Set Covering with Cutting Planes from Conditional Bounds. Egon Balas.

934. An Equivalence Between Two Algorithms for Quadratic Programming. Jong-Shi Pang.

935. Multiple-Object, Discriminatory Auctions with Bidding Constraints: A Game-Theoretic Analysis. Thomas R. Palfrey.

936. A Latent Time Series Model of the Cyclical Behavior of Interest Rates. Kenneth J. Singleton.

937. Maturity-Specific Disturbances and the Term Structure of Interest Rates. Kenneth J. Singleton.

938. On Parsimonious Explanations of Production Relations. Herbert A. Simon.

939. Stagflation, Persistent Unemployment and the Permanence of Economic Shocks. Karl Brunner, Alex Cukierman, and Allan H. Meltzer.

940. An Aversion to Positive Risks and Preference for Negative Risks. Benjamin Eden.

941. Property Tax Consciousness. Peter C. Ordeshook.

942. Vote Trading: An Experimental Study. Richard D. McKelvey and Peter C. Ordeshook.

943. Political Disequilibrium and Scientific Inquiry: A Comment on William Riker's "Implicetions from the Disequilibrium of Majority Rule for the Study of Institutions." Peter C. Ordeshook.

944. Differential Inflationary Expectations and the Variability of the Rate of Inflation: Theory and Evidence. Alex Cukierman and Paul Wachtel.

945. Expectations Models of the Term Structure and Implied Variance Bounds. Kenneth J. Singleton.

946. Realities of Improving the Quality of Work Life. Quality of Work Life Projects in the 1980s. Paul S. Goodman.

947. Optimal Challenges for Selection. Morris H. DeGroot and Joseph B. Kadane.

948. An Introduction to Corporate Accounting Standards: A Review. Yujl ljiri.

949. Multinational Inflation Under Fixed Exchange Rates: Some Empirical Evidence from Latent Variable Models. Edgar L Feige and Kenneth J. Singleton.

950. A Column Generation Technique for the Computation of Stationary Points. Jong-Shi Pang.

952. Some $n$ by dn Linear Complementarity Problems. Ikuyo Kaneko and Jong-Shi Pang.

953. Keynes's General Theory: A Different Perspective. Allan H. Meltzer.

954. Maximum Likelihood "Confirmatory" Factor Analysis of Economic Time Series. John F. Geweke and Kenneth J. Singleton.

955. A Unification of Two Classes of Q-Matrices. Jong-Shi Pang.

956. The Roles of Jurisdictional Competition and of Collective Choice Institutions in the Market for Local Public Goods. Dennis Epple and Allan Zelenitz.

(continued on back cover) 
The present serles containe articles writien by the faculty of the Graduate school of Induetrial Nominiatration. Publlcatione began in the $1962-63$ academic year and continue through to date. You may requeat coples and recoive them from: Repint Secrotary, CSIA, Carneglo-Melion Unlversity, Pittoburgh, Penna, 15213.

957. Databaee Location in Computer Networks. Marshall L. Fisher and Dorit S. Hochbaum.

958. Applications of the Operator Theory of Parametric Programming for the Transportation and Cenerallzed Transportation Problems. V. Balachandran, V. Srinivasan, and G. L. Thompeon.

959. A Reatricted Lagrangean Approach to the Traveling Salesman Problem. Egon Balas and Nicos Chriatolides.

890. Rete of Retum Indexes for GNMA Securities. Kenneth B. Dunn and John J. McConnell.

961. Only Normal Distributions Have Linear Posterlor Expectations in Linear Regression. Pren K. Cool and Mortis H. DeCroot.

862. Municlpal Penslon Funding: A Theory and Some Evidence. Dennis Epple and Katherine Sonloper.

868. The Strateglc Potroleum Reserve: How Large Should It Be? Egon Balas.

984. Rates of Retum on CNMA Securtities: The Cost of Mortgage Funds. Kenneth B. Dunn and John J. Moconnell.

965. A Comparison of Alternative Models for Pricing GNMA Mortoage-Backed Securities. Kenneth B. Bunn and John J. McConnell.

8e8. Fonvard Algorthme for Fonward-Thinking Managers. Thomas E. Morton.

987. An Inctitutional Theory of the Effect of Intergovernmental Grants. Thomas Romer and Howard Rosonthal.

988. Valuation of CMMA Mortgage-Backed Securitles. Kenneth B. Dunn and John J. Moconnell.

969. Information About Hyporparametere in Hierarchical Models. Prem K. Goel and Morris H. Dectoot.

970. Hellum: Investments in the Future. Dennis Epple and Lester Lave.

971. Roeource Alocation Under Abymmetric Information. Mition Harris and Robert M. Townsend.

974. A Rational Theory of the Size of Government. Allan H. Meltzer and Scott F. Richard.

975. A Hybrid Method for the Solution of Some Multi-Commodity Spatial Equilibrium Problems. Jong-shl Pang.

976. Optimal Matching: A Survey. Morrie H. DeGroot.

978. A Recursive Method for Solving Assignment Problems. Gerald L. Thompson.

979. A Theory of Monopoly Prlcing Schemes with Demand Uncertainty. Milton Harris and Artur Raviv.

980. Appliance Performance Labeling and Point-of-Purchase Information: The Results of Three Experiments. Richard Staelin.

982. Judement Based Marketing Decision Models: Problems and Posslble Solutions. Dipankar Chakravartl, Androw Mltcholl, and Richard Staelin.

983. Integer and Fractlonal Matohings. Egon Balas.

984. Conflicting Objectives in Regulating the Automobile. Lester B. Lave.

888. Emplrical Analysls of the Commercial Loan Classification Decision. J. Richard Dletrich and Robert 8 . Kaplan.

989. Interlocking Directorates: A Strategy for Reducing Environmental Uncertainty. F. David Sohoorman, Max H. Bazerman, and Robert S. Atkin.

902. Are Product Attribute Beliefs the Only Medlator of Advertising Effects on Brand Attitude? Androw A. Mitchell and Jerry C. Olson.

t

Management intormation Systems: Progress and Perspectives (Carnegie Press, 1971).

Editore: C. H. Kriebel, R. L. Van Horn, and J. T. Heames. Price: $\$ 11.50$.

The Employment Came . . . Where Do You Flt? C. Douglas Mintmier, CsIA. Price: $\$ 5.95$ 